\title{
Isolation and identification of bacteria from fresh guava (Psidium guajava) sold at local markets in Mymensingh and their antibiogram profile
}

\author{
Md. Atiqur Rahman Sarker, Md. Mazedul Haque, Rafia Afroze Rifa, Fateha Akther Ema, Md. Ariful Islam and \\ Mst. Minara Khatun \\ Department of Microbiology and Hygiene, Bangladesh Agricultural University, Mymensingh-2202, Bangladesh. \\ Corresponding author: Mst. Minara Khatun, e-mail: mmkhatun@bau.edu.bd \\ Co-authors: MARS: tushar33vet@gmail.com, MMH: mazedul87@gmail.com, RAR: rafiaafroze05@gmail.com, \\ FAE: fatehaema.bau@gmail.com, MAI: islamma@bau.edu.bd \\ Received: 17-04-2018, Accepted: 11-07-2018, Published online: 23-08-2018
}

doi: 10.14202/vetworld.2018.1145-1149 How to cite this article: Sarker MAR, Haque MM, Rifa RA, Ema FA, Islam MA, Khatun MM (2018) Isolation and identification of bacteria from fresh guava (Psidium guajava) sold at local markets in Mymensingh and their antibiogram profile, Veterinary World, 11(8): 1145-1149.

\begin{abstract}
Aim: The study was conducted for the isolation, identification, and antibiogram of bacteria obtained from fresh guava (Psidium guajava).

Materials and Methods: A total of 25 fresh guavas were collected from five markets located in Mymensingh city. Guava samples were cultured onto various selective media such as eosin methylene blue, xylose lysine deoxycholate, thiosulfatecitrate-bile salts-sucrose, blood agar, and mannitol salt agar for the isolation of bacteria. Biochemical tests (dextrose, maltose, lactose, sucrose, mannitol, methyl red, Voges-Proskauer, and indole) were performed to identify the bacteria.

Results: Total viable counts of guava were ranged between $\log 6.56$ colony-forming unit (cfu)/ml and $6.62 \mathrm{cfu} / \mathrm{ml}$. A total of 106 bacterial isolates belonged to five genera (Escherichia coli, Salmonella spp., Vibrio spp., Bacillus spp., and Staphylococcus spp.) were identified. Salmonella spp. (23.6\%) was the most prevalent, followed by E. coli (22.64\%), Bacillus spp. (19.81\%), Staphylococcus spp. (17.92\%), and Vibrio spp. (16.03\%). The results of antibiotic sensitivity test showed that Salmonella spp., Bacillus spp., and E. coli were sensitive to chloramphenicol, ciprofloxacin, and gentamicin and resistant to ampicillin and cephalexin. Vibrio spp. was sensitive to chloramphenicol and gentamicin, intermediately sensitive to ciprofloxacin and ampicillin and resistant to cephalexin.
\end{abstract}

Conclusion: The results of this study indicate that fresh guava contains multidrug-resistant bacteria which might pose a public health risk.

Keywords: antibiogram profile, bacteria, guava, identification, isolation, Mymensingh.

\section{Introduction}

Among indigenous fruits, guava is one of the popular fruits in Bangladesh. Guava is often called the "apple of the tropics" belonging to the family Myrtaceae and the scientific name is Psidium guajava. Guava stands fifth in production among the most important fruit crops of Bangladesh and is grown all over the country. According to "Yearbook of Agricultural Statistics-2015," annual guava production in Bangladesh during 2014-2015 from inside and outside garden is 2,06,425 metric tons [1]. Guava has excellent medicinal, pharmacological, digestive, and nutritive values with pleasant flavor, high palatability, and availability in abundance at a moderate price [2].

Guava is a fresh fruit which is consumed raw without processing, thus posing a potential food safety problem by any pathogenic microorganism.

Copyright: Sarker, et al. Open Access. This article is distributed under the terms of the Creative Commons Attribution 4.0 International License (http://creativecommons.org/licenses/by/4.0/), which permits unrestricted use, distribution, and reproduction in any medium, provided you give appropriate credit to the original author(s) and the source, provide a link to the Creative Commons license, and indicate if changes were made. The Creative Commons Public Domain Dedication waiver (http://creativecommons.org/ publicdomain/zero/1.0/) applies to the data made available in this article, unless otherwise stated.
Improper handling can damage fresh produce, rendering the product susceptible to the growth or survival of spoilage and pathogenic microorganisms. The guavas provide a great problem in storage and transportation because of their perishable nature [3]. In addition to inherent activities, fruits are exposed to microbial contamination through contact with soil, dust, and water. As a result, guava fruits harbor a diverse range of microorganisms [4]. Hence, in this viewpoint, assessing the microbial spectrums of guava obtained from the market is essential. Microbiological quality of some commercially packed and fresh fruit juice available in Dhaka city has been performed [5].

It is evident that no survey or assessment of guava fruit safety has yet been conducted in Bangladesh. Therefore, the objective of the present study was to isolate, identify and antimicrobial profile of bacteria isolated from fresh guava fruits sold at five markets in Mymensingh city.

\section{Materials and Methods}

\section{Ethical approval}

The present study was conducted during the period from July to December 2013, in the Bacteriology Laboratory of the Department of Microbiology and 
Hygiene, Faculty of Veterinary Science, Bangladesh Agricultural University (BAU), Mymensingh.

\section{Collection and transportation of samples}

Guava samples were collected from KR market, Sheshmor, Kewatkhali, Meshubazar, and Nutunbazar (Table-1). Samples were collected in sterile polythene bags separately. The samples were transported carefully to the Bacteriology Laboratory of the Department of Microbiology and Hygiene, BAU, Mymensingh, for bacteriological analysis.

\section{Processing of guava samples}

Each guava sample was washed with $20 \mathrm{ml}$ sterile PBS and transferred the washing sample into separate poly bag. A ten-fold serial dilution of the samples was performed in the nutrient broth.

\section{Determination of total viable count (TVC)}

$0.5 \mathrm{ml}$ of each 10 -fold diluted sample was transferred and spread on Plate Count Agar using a sterile pipette and a sterile glass spreader. Then, the plates were kept in an incubator at $37^{\circ} \mathrm{C}$ for $24-48 \mathrm{~h}$. The number of colonies in a particular dilution was multiplied by the dilution factor to obtain TVC which was expressed as a mean $\log 10 \pm$ standard deviation colony-forming unit (cfu) per ml.

\section{Isolation of bacteria in pure culture}

The isolation and identification of bacteria were performed according to the method described by Carter [6]. Samples were enriched in nutrient broth at $37^{\circ} \mathrm{C}$ for $24 \mathrm{~h}$. The overnight cultures were streaked on SS agar (for Salmonella spp.), eosin methylene blue (EMB) (for Escherichia coli), BA (for Bacillus spp.), MS agar (for Staphylococcus spp.), and thiosulfate-citrate-bile salts-sucrose (TCBS) agar (for Vibrio spp.). The inoculated plates were incubated at $37^{\circ} \mathrm{C}$ for $24 \mathrm{~h}$. A single colony was further subcultured until pure culture was obtained. Identification of bacteria was performed on the basis of colony morphology, Gram's staining reaction, motility test, and biochemical tests.

\section{Molecular detection of $E$. coli by polymerase chain reaction (PCR) \\ DNA extraction}

A pure bacterial colony of E. coli was mixed with $100 \mu$ of distilled water which was boiled for $10 \mathrm{~min}$ and then immediately kept on ice for cold shock. Finally, centrifugation was done at 10,000 rpm for $10 \mathrm{~min}$. The supernatant was collected and used as a DNA template for PCR.

\section{Primers used for $P C R$}

A genus-specific PCR was performed to amplify 16S rRNA of E. coli using previously published primers [7]. The list of primers is shown in Table-2.

\section{Antibiotic sensitivity test}

Five isolates randomly selected from five genera were tested for antimicrobial drug susceptibility against five commonly used antibiotics by disc diffusion or Kirby-Bauer method [8]. Selection of 3-5 well-isolated colonies from the SS, BA, EMB, MS, and TCBS agar plate. Touched the top of colony with a loop and the growth is transferred into the nutrient broth. The broths were streaked onto Mueller-Hinton agar plates using sterile glass spreader homogeneously. Then, the antibiotic disc was placed onto Muller-Hinton agar and incubated at $37^{\circ} \mathrm{C}$ for $24 \mathrm{~h}$. The plates were examined, and the diameter of the zones of inhibition was measured in $\mathrm{mm}$ from the edge of the disc to the edge of the zone using a meter ruler.

\section{Statistical analysis}

The results of TVC of the bacteria of guava sold at local markets were analyzed for statistical significance using [9] multiple range test (SPSS 11.5, US). A $p \leq 0.01$ was considered to be statistically significant.

\section{Results}

\section{TVC of guava}

The bacterial load was the highest in Nutunbazar sample $(\log 6.62 \pm 0.02 \mathrm{cfu} / \mathrm{ml})$, followed by Kewatkhali $(\log 6.60 \pm 0.03 \mathrm{cfu} / \mathrm{ml})$, Meshubazar $(\log 6.58 \pm 0.04 \mathrm{cfu} / \mathrm{ml})$, and $\mathrm{KR}$ market (log $6.57 \pm 0.03 \mathrm{cfu} / \mathrm{ml})$. The lowest TVC was recorded in Sheshmor at BAU campus ( $\log 6.56 \mathrm{cfu} / \mathrm{ml})$. The bacterial load recorded in guava sold at all local markets did not vary and was found to be statistically significant ( $p=0.0007$ ). The TVC of the guava samples collected from different markets is presented in Table-3.

Table-1: Summary of samples used for the isolation of bacteria.

\begin{tabular}{lcc}
\hline Name of markets & $\begin{array}{c}\text { Sample number of guava } \\
\text { collected }\end{array}$ & Total \\
\hline KR market & 5 & 25 \\
Sheshmor & 5 & \\
Kewatkhali & 5 & \\
Meshubazar & 5 & \\
Nutunbazar & 5 & \\
\hline
\end{tabular}

Table-2: PCR primers with the sequence.

\begin{tabular}{llc}
\hline Primer & Sequence & $\begin{array}{c}\text { Size } \\
\text { (bp) }\end{array}$ \\
\hline E. coli 16S (F) & 5'-AATTGAAGAGTTTGATCATG-3' & 704 \\
E. coli 16S (R) & 5'-CTCTACGCATTTCACCGCTAC-3' & \\
\hline
\end{tabular}

$\mathrm{F}=$ Forward, $\mathrm{R}=$ Reverse, $\mathrm{bp}=$ Base pair, $\mathrm{PCR}=$ Polymerase chain reaction, E. coli=Escherichia coli

Table-3: Total viable count (TVC) of guava sold at local market in Mymensingh

\begin{tabular}{lcc}
\hline $\begin{array}{l}\text { Markets } \\
\text { name }\end{array}$ & TVC (mean log CFU $\mathbf{S D} / \mathbf{m I})$ & p-value \\
\hline Sheshmor & $6.56 \pm 0.024$ & $0.0007 * *$ \\
KR market & $6.57 \pm 0.03$ & \\
Kewatkhali & $6.60 \pm 0.03$ & \\
Nutunbazar & $6.62 \pm 0.02$ & \\
Meshubazar & $6.58 \pm 0.04$ & \\
\hline$* *=$ Significant at 1\% level of probability $(\mathrm{P}<0.01)$
\end{tabular}


Isolation of bacteria from guava surface samples

Five genera of bacteria such as E. coli, Salmonella spp., Vibrio spp., Bacillus spp., and Staphylococcus spp. were isolated from guava samples.

\section{Sugar fermentation and biochemical tests}

The results of sugar fermentation tests using five basic sugars such as dextrose, maltose, lactose, sucrose, and mannitol are presented in Table-4. Acid and gas production was indicated by the change of color of phenol red from red to yellow and the presence of gas bubbles in Durham tube. The negative reaction was indicated by no change of color.

\section{Distribution of bacterial isolates from guava sold at the local market}

The number of bacterial isolates detected in guavas sold at five local markets is presented in Figure-1.

Overall frequency distribution of $E$. coli, Salmonella spp., Vibrio spp., Bacillus spp., and Staphylococcus spp.

A total of 106 bacterial isolates were obtained from 25 guava samples. The frequency distribution of E. coli was $22.64 \%$ (24 of 106), Salmonella spp. was $23.60 \%$ (25 of 106), Vibrio spp. was $16.03 \%$ (17 of 106), Bacillus spp. was 19.81\% (21 of 106), and Staphylococcus spp. was $17.92 \%$ (19 of 106). Overall frequency distribution of E. coli, Salmonella spp., Vibrio spp., Bacillus spp., and Staphylococcus spp. is shown in a pie chart (Figure-2).

\section{Molecular detection of $E$. coli}

DNA extracted from five $E$. coli isolates was used in the PCR assay. PCR primers targeting 16S rRNA of $E$. coli amplified 704 bp fragments of DNA confirmed the identity of E. coli (Figure-3).

\section{Results of Antibiotic Sensitivity Tests}

A total of five isolates such as E. coli, Salmonella spp., Vibrio spp., Bacillus spp., and Staphylococcus spp. were subjected to antibiotic sensitivity assay. Summary of antibiogram profile of $E$. coli, Salmonella spp., Bacillus spp., Vibrio spp., and Staphylococcus spp. against antibiotics is presented in Figure-4.

\section{Discussion}

Consumption of fresh fruit is increasing significantly in the recent days. Fruits usually do not receive any treatment, as a result, they are prone to get contaminated with foodborne and antibiotic-resistant bacteria that may cause public health hazards. In this study, TVC of bacteria of the washed sample of guavas sold at five local markets in Mymensingh ranged from $\log 6.56$ to $6.62 \mathrm{cfu} / \mathrm{ml}$. Oranusi et al. [10] stated that the acceptable microbial count in fruit juices suitable for human consumption ranged from $\log 4 \mathrm{cfu} / \mathrm{ml}$ to $\log 5 \mathrm{cfu} / \mathrm{ml}$. The microbial load on guava recorded

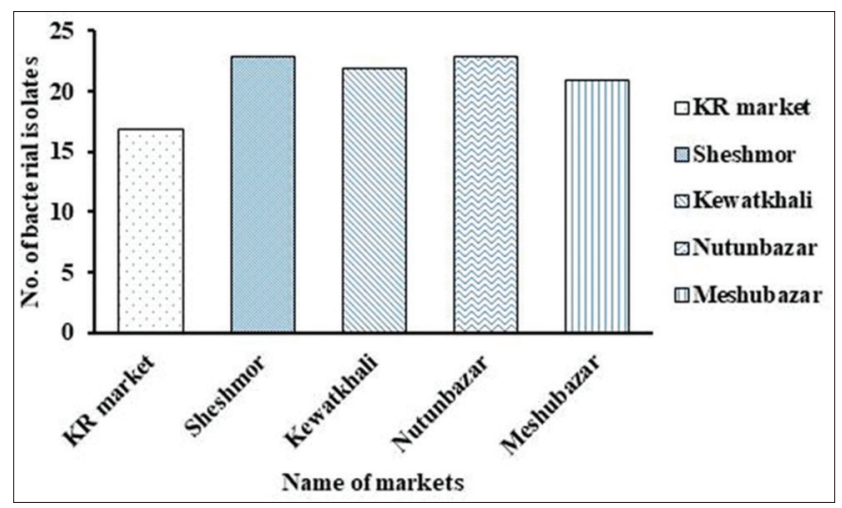

Figure-1: Number of bacterial isolates recovered from guava sold at local markets in Mymensingh. The highest number of bacteria were recovered from Sheshmor and Nutunbazar (23 isolates from 5 samples), followed by Kewatkhali (22 isolates from 5 samples), Meshubazar (21 isolates from 5 samples), and KR market (17 isolates from 5 samples).

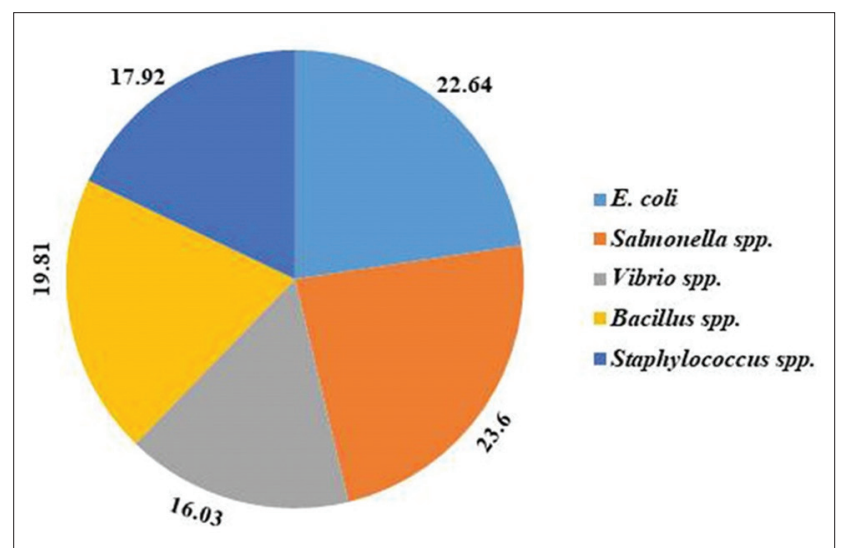

Figure-2: Overall percentage distribution of Escherichia coli, Salmonella spp., Vibrio spp., Bacillus spp., and Staphylococcus spp. in 25 guava samples sold at KR market, Sheshmor, Kewatkhali, Nutunbazar, and Meshubazar in Mymensingh.

Table-4: Biochemical characteristics of E. coli, Salmonella spp., Vibrio spp. Bacillus spp., and Staphylococcus spp.

\begin{tabular}{|c|c|c|c|c|c|c|c|c|}
\hline \multicolumn{5}{|c|}{ Sugar fermentation reaction profiles } & \multirow[t]{2}{*}{ MR test } & \multirow[t]{2}{*}{ VP test } & \multirow[t]{2}{*}{ Indole production test } & \multirow[t]{2}{*}{ Interpretation } \\
\hline $\mathbf{D X}$ & ML & $\mathbf{L}$ & $\mathbf{S}$ & MN & & & & \\
\hline AG & $A G$ & AG & AG & AG & + & - & + & E. coli \\
\hline A & $A$ & - & - & A & + & - & - & Salmonella spp. \\
\hline A & $A$ & - & A & A & + & - & + & Vibrio spp. \\
\hline AG & $A$ & $A$ & AG & AG & - & - & + & Bacillus spp. \\
\hline A & $A$ & $A$ & A & $A$ & + & + & - & Staphylococcus spp. \\
\hline
\end{tabular}

Legend: $\mathrm{DX}=$ Dextrose, $\mathrm{ML}=$ Maltose, $\mathrm{L}=$ Lactose, $\mathrm{S}=$ Sucrose, $\mathrm{MN}=$ Mannitol, $\mathrm{A}=\mathrm{Acid}, \mathrm{AG}=\mathrm{Acid}$ and $\mathrm{Gas}$, "+ $=$ Positive "-"=Negative, "MR"=Methyl red, "VP"=Voges-Proskauer 


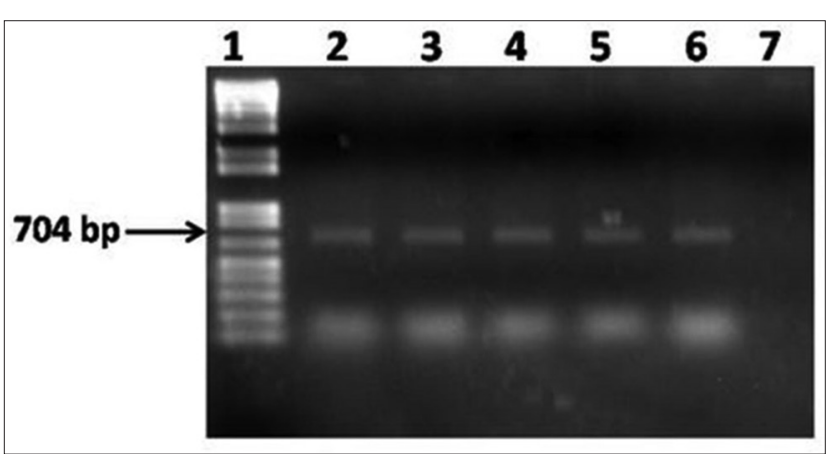

Figure-3: Polymerase chain reaction assay to amplify $16 \mathrm{~S}$ rRNA of Escherichia coli isolates of guava sold at five local markets in Mymensingh. Lane 1: $100 \mathrm{bp}-12 \mathrm{~kb}$ size DNA marker (TrackIt, Invitrogen, USA); lane 2: E. coli isolates of guava at KR market; lane 3: E. coli isolate of guava at Sheshmor; lane 4: E. coli isolate of guava at Kewatkhali; lane 5: E. coli isolate of guava at Nutunbazar; lane 6: E. coli isolate of guava at Meshubazar; lane 7: Negative control without DNA.

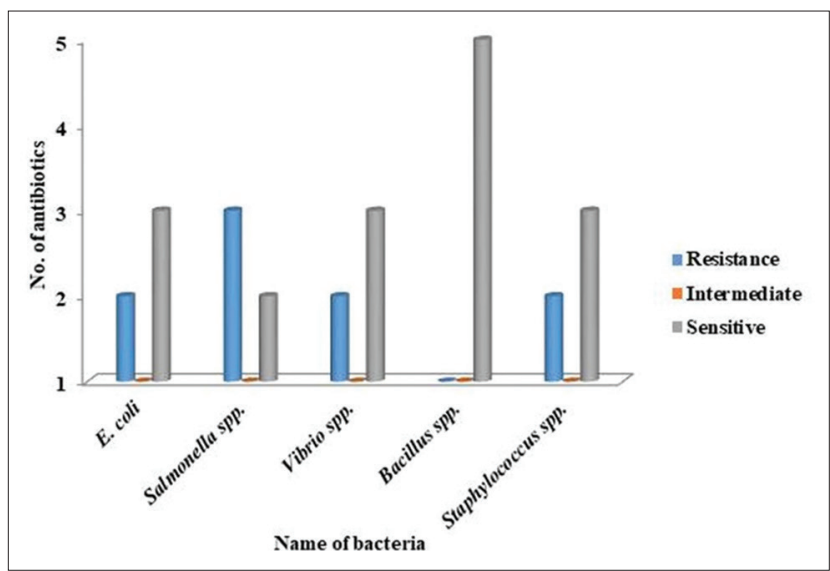

Figure-4: Summary of antibiogram profile of Escherichia coli, Salmonella spp., Vibrio spp., Bacillus spp., and Staphylococcus spp. against five antibiotics. E. coli was sensitive to three and resistant to two antibiotics, Salmonella spp. was sensitive to two and resistant to three antibiotics, Vibrio spp. was sensitive to three and resistant to two antibiotics, Bacillus spp. was sensitive to five but no resistant or intermediately resistant to any antibiotics, and Staphylococcus spp. was sensitive to three and resistant to two antibiotics.

in this study exceeded the acceptable limit. In another study, total viable bacterial count in guava samples was observed within the range of $10^{2}-10^{7} \mathrm{cfu} / \mathrm{g}$ [11].

In this study, 106 bacterial isolates belonged to five genera (such as E. coli, Salmonella spp., Vibrio spp., Bacillus spp., and Staphylococcus spp.) were identified. Eni et al. [12] isolated Staphylococcus aureus, E. coli, and Salmonella spp. from fruits and vegetables purchased from vendors. Mrityunjoy et al. [13] detected Vibrio cholerae in vegetables and fruits sold in Dhaka city. In this study, the distribution percentages of E. coli, Salmonella spp., Vibrio spp., Bacillus spp., and Staphylococcus spp. in guava were $22.64 \%, 23.60 \%, 16.03 \%, 19.81 \%$, and $17.92 \%$, respectively, which are nearly similar to the findings of Akhtar et al. [14], i.e. Klebsiella pneumoniae (25\%), E. coli $(21 \%)$, Serratia marcescens $(12.5 \%)$,
Pseudomonas aeruginosa (17\%), Bacillus cereus $(16.5 \%)$, and S. aureus (8\%). Mukharjee et al. [15] reported $1.6 \%$ and $9.7 \%$ prevalence of $E$. coli in conventional and organic fruits grown by Minnesota farmers in the USA. Eni et al. [12] recorded 4.2\%, 12.5\%, and $29.2 \%$ prevalence of E. coli, Salmonella spp., and $S$. aureus in fruits and vegetables, respectively. Chikere and Azubuike [16] isolated Bacillus, E. coli, Enterobacter, Salmonella, Shigella, Pseudomonas, and Staphylococcus from guava samples in Nigeria. Contamination of guava with foodborne bacteria might be resulted from poor hygiene of the vendor, using microbial unsafe container, poor handling practice, and unsanitary market condition [17].

The occurrence of antibiotic-resistant bacteria in agricultural food staff is emerging throughout the world [17-19]. Antibiotic-resistant bacteria are known to spread from fruits and vegetables to human through the food chain. In this study, four genera of bacteria such as E. coli, Salmonella spp., Vibrio spp., and Staphylococcus spp. were found multidrug resistant (resistant against 2-3 antibiotics). Antibiotics against which bacterial isolates of guava were found resistant were ampicillin and cephalexin (E. coli, Vibrio spp., and Staphylococcus spp.), chloramphenicol, ampicillin, and cephalexin (Salmonella spp.). In the current study, no resistance was observed in the case of Bacillus spp. isolated from guava. Rashed et al. [19] identified multidrug-resistant E. coli and Staphylococci in fruit juice sample sold at Dhaka city. Nawas et al. [20] isolated multidrug-resistant Salmonella spp. and Vibrio spp. from salad vegetables. Antibiotic-resistant bacteria in plant food staffs are known to occur from the use of antibiotics in plant agriculture [21]. Application of animal manure to the agricultural field can also spread drug-resistant bacteria to plant [18].

\section{Conclusion}

Data of this study suggest that guava sold at local markets of Mymensingh city harbors multidrug-resistant bacteria which underscore the need of the implementation of proper hygienic measures during pre- and post-harvest stages of production and at the time of transportation, storage, selling, and preparation of different products such as juices to safeguard public health.

\section{Authors' Contributions}

MMK and MAI designed the study. MARS and $\mathrm{MMH}$ collected and processed the samples for the isolation and identification of bacteria. MARS and MMH performed PCR and electrophoresis. MARS, MMH, and RAR did antibiotic sensitivity test. MARS, FAE, and MMK interpreted the results and analyzed the data. MARS, MAI, and MMK prepared the manuscript. All authors read and approved the final manuscript.

\section{Acknowledgments}

We want to thank the Bangladesh Agricultural University Research System for providing the 
financial support (Project no. 2014/05/BAU) to carry out the work.

\section{Competing Interests}

The authors declare that they have no competing interests.

\section{References}

1. Yearbook of Agricultural Statistics-2015, 27 $7^{\text {th }}$ Series. (2016). Bangladesh Bureau of Statistics (BBS), Statistics and Informatics Division (SID), Ministry of Planning Government of the People's Republic of Bangladesh. Available from: http://www.bbs.gov.bd. Last accessed on 31-03-2018.

2. Shruthi, S.D., Roshan, A., Timilsina, S.S. and Sunita, S. (2013) A review on the medicinal plant Psidium guajava Linn. (Myrtaceae). J. Drug Deliv. Ther., 3: 162-168.

3. Baldwine, E. and Mitra, S. (1997) Post-Harvest Physiology and Storage of Tropical and Subtropical Fruits. International Wallingford, UK. p85-122.

4. Rover, D.C. (1998) Microbial safety evaluations and recommendations on fresh produce. Food Contr., 9: 321-347.

5. Rahman, T., Hasan, S. and Noor, R. (2011) An assessment of microbiological quality of some commercially packed and fresh fruit juice available in Dhaka city: A comparative study. Stamford J. Microbiol., 1: 13-18.

6. Carter, G.R. (1955) Studies on Pasteurella multocida. I. A hemagglutination test for the identification of serological types. Am. J. Vet. Sci., 16: 481-484.

7. Guan, S., Xu, R., Chen, S., Odumeru, J. and Gyles, C. (2002) Development of a procedure for discriminating among Escherichia coli isolates from animal and human sources. Appl. Environ. Microbiol., 68: 2690-2698.

8. Bauer, A.W., Kirby, W.M.M., Shrris, J.C. and Truck, M. (1966) Antibiotic susceptibility testing by a standardized single disc method. Am. J. Clin. Pathol., 45: 493-496.

9. Duncan, D.B. (1955). Multiple range and multiple F test. Biometrics, 11: 1-42.

10. Oranusi, U.S., Braide, W. and Neziyana, H.O. (2012) Microbiological and chemical quality assessment of some commercially packed fruit juices sold in Nigeria. Greener J. Biol. Sci., 2: 1-6.
11. Akter, R., Tanu, N.I. and Uddin, M.A. (2013) Isolation and quantification of bacterial isolates from citrus fruits and determination of their anti-bacterial activity against selected pathogens. Stamford J. Microbiol., 3: 30-33.

12. Eni, A.O., Angela, O.I. and Solomon, O.U. (2010) Microbial quality of fruits and vegetables sold in Sango Ota, Nigeria. Afr. J. Food Sci., 4: 128-134.

13. Mrityunjoy, A., Kaniz, F., Fahmida, J., Shanzida, J.S., Aftab, U. and Rashed, N. (2013) Prevalence of Vibrio cholerae in different food samples in the city of Dhaka, Bangladesh. Int. Food Res. J., 20: 1017-1022.

14. Akhtar, T., Rahman, M.R., Biswas, S., Perveen, R., Alam, M.S., Khanum, F.A., Islam, M.A., Biswas, S., Keya, C.A. and Manirujjaman, M. (2016) Identification of microbial contamination of popular fruits of Bangladesh and assessment the effects of alternative preservatives instead of formalin. Am. J. Microbiol. Res., 4: 138-142.

15. Mukherjee, A., Speh, D., Dyck, E. and Diez, G.F. (2004) Preharvest evaluation of coliforms, Escherichia coli, Salmonella, and Escherichia coli 0157:H7 in organic and conventional produce grown by Minnesota farmers. J. Food Prot., 67: 894-900.

16. Chikere, C.B. and Azubuike, C.C. (2014) Microbial composition of guava (Psidium guajava). hibiscus (Hibiscus-rosa sinensis), mango (Mangifera indica) and Pumpkin (Telfairia occidentalis Hook) phyllosphere. Afr. J. Biotechnol., 13: $1859-1866$

17. Gultie, A. and Sahile, S. (2013) Microbial spectrum of fruit in Gondar town markets, North Western Ethiopia. $J$. Microbiol. Res., 3: 1-10.

18. Boehme, S., Werner, G., Klare, I. and Witte, W. (2004) Occurrence of antibiotic-resistant Enterobacteria in agricultural foodstuffs. Mol. Nutr. Food Res., 48: 522-531.

19. Rashed, N., Aftab, M.U., Azizul, M.H., Saurab, K.M., Mrityunjoy, A. and Majibur, M.R. (2013) Microbiological study of vendor and packed fruit juices locally available in Dhaka city, Bangladesh. Int. Food Res. J., 20: 1011-1015.

20. Nawas, T., Mazumdar, R.M., Das, S., Nipa, N.N., Islam, S., Bhuiyan, H.R. and Ahmad, I. (2012) Microbiological quality and antibiogram of E. coli, Salmonella and Vibrio of salad and water from restaurants of Chittagong. J. Environ. Sci. Nat. Resour., 5: 159-166.

21. Falkiner, F.R. (1998) The consequence of antibiotics used in horticulture. J. Antimicrob. Chemother., 41: 429-431. 